\title{
IGLESIA Y POLÍTICA EL EFECTO KARADIMA
}

María Olivia Mönckeberg Pardo 


\section{MARÍA OLIVIA MÖNCKEBERG PARDO}

Profesora titular de la Universidad de Chile, directora del Instituto de la Comunicación e Imagen (ICEI) de la misma Universidad y Premio Nacional de Periodismo 2009. Es autora de los libros El saqueo de los grupos económicos al Estado de Chile (2001); El Imperio del Opus Dei en Chile (2003); La privatización de las universidades, una historia de dinero, poder e influencias (2005); El negocio de las universidades en Chile (2007); Los magnates de la prensa, concentración de los medios de comunicación en Chile (2009); y Karadima, el señor de los infiernos (2011). 


\section{IGLESIA Y POLÍTICA \\ EL EFECTO KARADIMA}

Cuando en abril de 2010 trascendió que el ex párroco de la influyente iglesia de El Bosque, Fernando Karadima Fariña, era acusado de abuso, las fuerzas ligadas a los poderes político, económico y comunicacional surgieron rápidas, en una cerrada defensa, mientras ponían en cuestión la credibilidad de las víctimas. Duros juicios de algunos altos dignatarios eclesiásticos aparecieron en las páginas de los diarios y en imágenes de televisión, incluso antes de que el médico James Hamilton, el periodista Juan Carlos Cruz, el filósofo José Andrés Murillo y el abogado Fernando Batlle hicieran públicas sus denuncias.

Las páginas de los medios de prensa "convencional", en particular las de los diarios de la cadena de Agustín Edwards, se abrieron para dar cabida a los cercanos de Karadima. Los lazos de su círculo de protección golpeaban a las víctimas, mientras los feligreses y admiradores se resistían a dar crédito a lo que escuchaban y leían. Artículos, crónicas y cartas al director trataron de hacer lo imposible por avalar la inocencia del ex párroco y desacreditar a los denunciantes que a esa altura solo eran "presuntos".

El obispo auxiliar de Santiago, Andrés Arteaga -quien en ese momento se desempeñaba también como vicegrancanciller de la Universidad Católica- manifestó de inmediato su irrestricto apoyo a su mentor Fernando Karadima ${ }^{1}$. También se escuchó firme y lapidaria contra los denunciantes la voz del entonces vicedecano de la Facultad de Teología de la misma pontificia Universidad, Rodrigo Polanco, quien calificó las acusaciones de "calumnia sin fundamento y grosera"2.

A esos integrantes de la Pía Unión Sacerdotal y la organización encabezada por el ex párroco de El Bosque, se sumaron otros personajes del mundo militar, del ambiente político y de grupos económicos: el general del Ejército (r) Eduardo Aldunate, quien había comandado las tropas chilenas en Haití, aseguró al diario La Segunda que había conocido a Karadima cuarenta años atrás, cuando estaba en la Escuela Militar, y señaló que era "un sacerdote tremendamente dedicado a su vocación"3.

Uno de los primeros en salir en defensa acérrima de Karadima fue Alejandro GarcíaHuidobro, entonces diputado de la UDI, quien fue designado senador por su partido tras el cambio de gabinete de julio de 2011. Con sentidas palabras el parlamentario manifestó: "Simplemente no lo puedo creer... En el grupo parroquial se han formado 80 sacerdotes y cinco obispos... Es nuestro padre espiritual. Doy fe que en las miles de veces que hemos estado en retiros, en reuniones, en adoraciones al Santísimo nunca el padre Fernando andaba solo con una persona, siempre se acompañaba de dos o tres. Siempre se cuidaba. Es una persona que lo único que nos inculcaba era valores, apoyo

1. "Cardenal confirma indagación a sacerdote y caso llega a la fiscalía", La Tercera, 22 de abril de 2010.

2. "ES una calumnia sin fundamento y grosera", El Mercurio 22 de abril de 2010.

3. "En misa de El Bosque algunos feligreses lo defendieron a viva voz", La Segunda, 21 de abril de 2010. 
al matrimonio. Para mí esto es imposible de creer. Acá puede haber otro tipo de intenciones... desprestigiar a la Iglesia"4, aventuró el senador.

El empresario José Said -dueño principal de Embotelladora Andina, del Parque Arauco y de la Isapre Cruz Blanca, entre otras actividades-, consideraba "inconcebible que se desprestigie a un sacerdote que ha hecho tanto por la Iglesia, sin haber terminado las investigaciones y sin un juicio justo"s. Más directos fueron los contactos que efectuó un tiempo después Eliodoro Matte Larraín, quien encabeza el grupo económico más influyente del país. El presidente de la Compañía Manufacturera de Papeles y Cartones y del Banco BICE, accionista controlador de la empresa eléctrica Colbún, uno de los principales benefactores de Karadima, no trepidó en ir a visitar el 12 de mayo de 2010 al fiscal Sabas Chahuán para intervenir por su amigo sacerdote. Y Pilar Capdevilla, la esposa de Matte, ya antes, tras la transmisión del programa Informe Especial de Televisión Nacional, había formado parte de un coro de connotados personajes que abogaban por la inocencia del cura, cuando señaló a través de las pantallas de televisión: "Jimmys Hamilton es un gran actor, debería irse a Hollywood"6.

Desde la misma Pía Unión Sacerdotal, otros discípulos de Karadima, como el sacerdote Francisco Javier Manterola -quien había sido vicario de la zona centro de la Región Metropolitana y antes secretario del ex arzobispo Francisco Javier Errázuriz-, y el mismo Rodrigo Polanco, orquestaron en secretas reuniones declaraciones tendientes a menoscabar el testimonio del doctor James Hamilton, el principal acusador del cura. Entretanto, asumió la defensa de Karadima el abogado Luis Ortiz Quiroga, uno de los más connotados penalistas, quien intentó censurar la difusión del programa Informe Especial de Televisión Nacional.

En esos días de abril de 2010, cuando el Secretario de Estado Vaticano Tarcisio Bertone se encontraba de visita en el país, todas las aristas del poder confluyeron para detener la ola que se venía encima de la Iglesia Católica chilena. Utilizando los más variados medios, sus conocidas influencias buscaban silenciar el que sería el mayor escándalo en su historia.

Pero esta vez las argucias comunicacionales no sirvieron.

\section{"BALUARTE" POLÍTICO}

Fernando Karadima Fariña había cumplido un rol político importante en la Iglesia chilena de las últimas décadas. Su discurso ultraconservador, el rito preconciliar que admiraba y practicaba en la parroquia de El Bosque, con mucho latín y ninguna guitarra, con misas cortas y abundantes limosnas y donaciones, le daba acogida a católicos que se sentían incómodos con obispos como Manuel Larraín, el Cardenal Raúl Silva Henríquez, o muchos más que -desde los años 60- hablaban del compromiso social de los

\footnotetext{
4. "En misa de El Bosque algunos feligreses lo defendieron a viva voz", La Segunda, 21 de abril de 2010.

5. Agencia AFP, 25 de abril de 2010.

6. Mönckeberg, $\mathrm{M}^{\mathrm{a}}$ O., Karadima, el señor de los infiernos, Santiago: Debate, 2011.
} 
cristianos, que se preocupaban por encíclicas, apoyaban la reforma agraria y combatían la injusticia. La jerarquía de la Iglesia católica entonces era enjuiciada con ojos críticos -y tildada de "roja" - por muchos de esos feligreses de El Bosque, quienes se apegaban a creencias, valores y ritos tradicionales.

Después de la elección presidencial de Salvador Allende en 1970, la amistad de Fernando Karadima con la familia Bulnes Cerda, y probablemente sus ideas anticomunistas, lo llevaron a dar refugio en el recinto parroquial a uno de los implicados en el asesinato del general René Schneider, Juan Luis Bulnes, hermano de Juan Pablo, su inseparable abogado. El propio cura relataba como "hazaña" esta acción a sus seguidores, cuando -años después- les hablaba sobre las bondades de Augusto Pinochet, y les decía que los muertos bajo la mano de la dictadura eran "bajas necesarias"

Karadima estuvo estrechamente ligado a la situación política que vivió Chile en esos años y los siguientes. Su parroquia representó durante décadas un baluarte para los sectores católicos más conservadores. Por eso, no es casual que su círculo de apoyo y sus redes de protección estén constituidos por lo más recalcitrante del empresariado y de la derecha católica dura.

Para esos sectores, El Bosque era un espacio privilegiado donde practicar su religiosidad a la manera de Karadima, a quien veneraban, lo recibían en sus casas con su séquito juvenil y le efectuaban importantes donaciones. Era para ellos un semidios.

Mientras la Iglesia de Silva Henríquez se preocupaba de defender los derechos humanos pisoteados, en El Bosque "todos eran pinochetistas" -como cuentan sus víctimas-, y Fernando Karadima preconizaba que Augusto Pinochet había sido puesto por Dios a la cabeza del país.

La presencia de militares, como el general Santiago Sinclair -quien fue comandante en jefe del Ejército, ministro Secretario General de la Presidencia y senador designado en los 90-, y del encargado de las relaciones con la Iglesia del Gobierno de entonces, Sergio Rillón, son reflejos de esa proximidad entre el régimen dictatorial y el ex párroco.

\section{LAS INFLUENCIAS DE UN "SANTO"}

Famoso por su elocuencia, sus seguidores le atribuían un "carisma especial", una suerte de don de la palabra que admiraban sus feligreses y amigos. A eso agregaba algunas "leyendas", entre las que estaba su proclamada admiración al padre Alberto Hurtado, de quien se decía discípulo, aunque subsisten fundadas dudas sobre la veracidad de las historias que relataba al respecto.

Con todo, durante años Karadima convocó a miles de jóvenes vinculados a los más acomodados sectores de Santiago. Y cientos de ellos, de generación en generación, lo rodeaban en forma permanente, seguían sus pasos y sus consejos con obediencia y rigor. Proyectó entre ellos, durante décadas, sus ideas conservadoras sobre sociedad y moral familiar. Sus admiradores más entusiastas decían que era un "santo en vida" y algunos

7. Ibíd. 
-incluidos sacerdotes y obispos- ya empezaban a dar curso a la posibilidad de elevarlo a los altares.

Karadima era el máximo proveedor de "vocaciones" sacerdotales en una iglesia en que estas ya no abundaban. Cerca de cincuenta curas -se ufanaba- le debían a él su decisión de consagrarse a Dios, mientras con orgullo destacaba que había "creado" cinco obispos. Su influencia en la Conferencia Episcopal era evidente, algunos de sus discípulos escalaban posiciones en la Facultad de Teología de la Universidad Católica y en la Iglesia de Santiago los nexos eran próximos: "sus" sacerdotes mantenían vínculos estrechos con el mentor, quien seguía siendo director espiritual y guía de todos ellos. Sus redes no tenían límites y su castillo parecía una fortaleza inexpugnable.

En diferentes ámbitos eclesiales se le respetaba y hasta se le aplaudía por esa trayectoria que lucía "frutos" tan evidentes. Sus discípulos se desplegaban en altos cargos de la curia y estaban -y están- a cargo de una proporción significativa de parroquias de la Región Metropolitana.

A eso se sumaba una histórica amistad con el ex Secretario de Estado Vaticano y actual decano del Colegio Cardenalicio en Roma, Angelo Sodano ${ }^{8}$, quien en su larga estadía como nuncio apostólico en Chile -entre 1978 y 1988- visitaba con frecuencia al cura de El Bosque, al punto que los jóvenes llamaban en esa época "la salita del nuncio" a la habitación en que se reunían ${ }^{9}$ Karadima y Sodano.

No es extraño entonces que el hoy condenado sacerdote tuviera más influencia al interior de la jerarquía que muchos obispos. Después de regresar a Roma, el mandato de Sodano en la secretaría de Estado se prolongó durante catorce años. Tan influyente contacto, además de la relación de Karadima con el Cardenal Jorge Medina Estévez, de similar corriente de pensamiento dentro de la Iglesia, fue significativo cuando se trató de elevar a la categoría de obispos a integrantes de la Pía Unión de El Bosque. El primero fue Felipe Bacarreza, quien después se alejó de su maestro. Más tarde vinieron Andrés Arteaga, Horacio Valenzuela, actual obispo de Talca, el obispo castrense Juan Barros y Tomislav Koljatic, obispo de Linares.

A simple vista la Conferencia Episcopal de Chile de los años 90 y de principios del siglo XXI iba acentuando una posición conservadora, y los hilos de Karadima llegaban hasta ella. Mientras, el reino que había logrado construir en la parroquia de la comuna de Providencia parecía una obra indestructible y loable para muchos católicos. Un bastión sólido e inquebrantable que merecía las bendiciones de Dios y los agradecimientos de los creyentes.

8. El cardenal Angelo Sodano es el decano del Colegio Cardenalicio de Roma desde 2005. Reemplazó en el cargo al actual Papa Benedicto XVI, Joseph Ratizinger. Sodano fue nuncio papal en Chile entre 1978 y 1988. Más tarde fue prosecretario de Estado del Vaticano entre 1990, hasta que en 1991, cuando fue investido como Cardenal, fue nombrado por Juan Pablo II Secretario de Estado del Vaticano. Se desempeñó en ese cargo -el segundo en importancia después del Papa- durante catorce años: entre 1991 y 2005. El cardenal Angelo Sodano es decano del Colegio Cardenalicio de Roma desde 2005. Reemplazó en el cargo al actual Papa Benedicto XVI, Joseph Ratzinger.

9. Op. Cit. 


\section{CUATRO CONTRA EL PODER}

La decisión del médico James Hamilton, el periodista Juan Carlos Cruz, el filósofo José Andrés Murillo y el abogado Fernando Batlle de contarle directamente a la sociedad con valentía y coraje lo que les había ocurrido en la parroquia de El Bosque logró derribar murallas y desarticular -en gran medida- esa máquina de dominación que había construido tenazmente Karadima desde comienzos de los años 60, y que seguía operando hasta el 2010.

Tras la denuncia pública entregada por Hamilton y Cruz al diario estadounidense New York Times, y la participación de los cuatro profesionales en el programa Informe Especial de Televisión Nacional de Chile en abril de 2010, las puertas del Arzobispado seguían prácticamente cerradas para las víctimas. Aunque después de cinco años, se desarrolló una investigación eclesiástica llevada por los promotores designados por la Iglesia $^{10}$, no hubo una actitud de acogida para las víctimas por parte del Cardenal arzobispo de Santiago Francisco Javier Errázuriz, quien debió ser su pastor, como han reclamado los denunciantes. Más aun, lo han acusado de encubrimiento, ya que él conoció los hechos mucho antes de encargar la investigación.

No obstante, fueron cada vez más los católicos y no católicos que iban entrando en sintonía con estos jóvenes profesionales que vieron sus vidas destruidas en manos del ex párroco y tuvieron la valentía de exponer lo que habían sufrido. La forma directa de relatar lo vivido, sin eufemismos ni contemplaciones, tan distinta a lo que es habitual en el medio local, lograron paso a paso generar una empatía con personas que sintieron con ellos su dolor y manifestaron su estupor. Rompieron barreras en la forma de comunicarse y marcaron un hito: se trataba de solo cuatro personas que se levantaban ante la conjugación de poderes que respaldaba a Karadima. Cuatro personas que no tuvieron miedo y estaban dispuestos a todo con tal de que se llegara a mostrar su verdad, a hacer justicia y a evitar que los brutales abusos psicológicos y sexuales que ellos habían experimentado se siguieran repitiendo.

El hecho de que las versiones coincidieran y a ellas se sumaran los testimonios entregados ante el fiscal Xavier Armendáriz por los de sacerdotes Hans Kast, Eugenio de la Fuente, y los hermanos Andrés y Fernando Ferrada, que habían sido formados por Karadima, fue otro antecedente importante para el esclarecimiento de esta historia de dominación ejercida durante décadas.

10. Los promotores de justicia eclesiástica fueron los sacerdotes Eliseo Escudero y Fermín Donoso, quienes recogieron los testimonios y prepararon el informe que sirvió de base para el veredicto de la Sagrada Congregación de la Fe en Roma, que declaró culpable de abusos y de violación del secreto de la confesión a Fernando Karadima. Más antecedentes en Mönckeberg, María Olivia, Karadima, el señor de los infiernos, Santiago: Debate, 2011. 


\section{JUICIOS Y CAREOS}

Con el correr de los meses y de los testimonios de Hamilton, de Cruz, de Murillo, de Battlle y de los otros testigos ante el fiscal Xavier Armendáriz, fue quedando claro que Karadima, su doble vida y sus abusivas prácticas, habían detonado la peor crisis que ha afectado a la Iglesia católica chilena. Su reino de más de cuarenta años a la cabeza de una verdadera secta se empezaba a derrumbar en medio de los ecos de situaciones similares ocurridas en los últimos años en diferentes países de Europa y América.

Hasta los más escépticos debieron inclinar la cabeza -al menos en público- ante el fallo del Vaticano, que a la vez impactó a la justicia chilena. El veredicto de Roma en febrero de 2011 cayó como una lápida sobre Karadima y sus incondicionales. El otrora poderoso y ensalzado párroco pasó a un enclaustramiento por decisión de la Sagrada Congregación de la Fe, que lo encontró culpable de abusos y de violar el secreto de confesión. Un mes después de asumir como nuevo arzobispo de Santiago, Ricardo Ezzati anunció: "Sobre la base de las pruebas adquiridas, el reverendo Fernando Karadima Fariña es culpable de los delitos mencionados en precedencia, y en modo particular, del delito de abuso de menor en contra de más víctimas, del delito contra el sexto precepto del Decálogo cometido con violencia, y de abuso de ministerio a norma canon 1389 del CIC [Catecismo de la Iglesia Católica]"11.

Ezzati agregó que «en consideración a la edad y del estado de salud del reverendo Fernando Karadima Fariña se considera oportuno imponer al inculpado retirarse a una vida de oración y de penitencia, también en reparación a las víctimas de abusos». Pero desde ese momento se le prohibió ejercer públicamente su ministerio sacerdotal, confesar y tener contacto con sus antiguos feligreses.

La confirmación del veredicto por parte de los obispos de Roma el 22 de junio último terminó de configurar un cuadro jamás imaginado para el cura, que no ha querido reconocer los hechos ni menos pedir perdón. Incluso en los careos a que fue sometido con sus víctimas en julio pasado, Karadima volvió a repetir lo que sus defensores trataron de argumentar desde el primer momento: todo esto sería una "confabulación".

Entretanto, durante 2010 el ex fiscal Xavier Armendáriz había avanzado en la investigación, hasta que intentó incautar los documentos sobre el proceso eclesiástico que estaban en manos del abogado de la defensa de Karadima, Juan Pablo Bulnes, un seguidor de Karadima por casi medio siglo. Cuando el juez de garantía lo frenó, Armendáriz debió dejar el proceso indagatorio. El caso pasó a la justicia antigua y cayó en manos de un novato y poco acucioso juez suplente, Leonardo Valdivieso, quien lo cerró sin profundizar en la investigación. El poder judicial daba así un pobre espectáculo. La justicia eclesial parecía ser más prolija.

Tras el fallo del Vaticano, hubo otros hechos que cambiaron el escenario: en febrero de 2010 un informe de la fiscal de la Corte de Apelaciones, María Loreto Gutiérrez, cuestionó el precipitado cierre del proceso. En el documento la fiscal planteaba que el

11. Parte de fallo del Vaticano dado a conocer en Santiago el 17 de febrero de 2011 por el arzobispo Ricardo Ezzati. 
caso debía pasar a la justicia criminal y recomendaba ejecutar todo lo que hasta ese momento se le había negado al fiscal regional cuando debió dejar sus indagaciones. A esto se sumó un convincente alegato del abogado de las víctimas, Juan Pablo Hermosilla, pidiendo la reapertura del caso y la designación de ministro en visita. Una impactante intervención de James Hamilton en el programa Tolerencia Cero de Chilevisión, en la que calificó de "criminal" la omisión del ex arzobispo Francisco Javier Errázuriz, agregó más antecedentes a la ya espinuda situación.

En ese clima, el Pleno de la Corte Suprema decidió reabrir el caso. Fue entonces el turno de una joven jueza, Jessica González, quien fue designada ministra en visita y se hizo cargo de una investigación que al cierre de estas páginas aún no terminaba. La ministra González emprendió desde el primer instante su tarea con dedicación y minuciosidad. No trepidó en interrogar a quien estimó necesario. Por su despacho desfilaron durante cuatro meses víctimas y testigos, y ella visitó personalmente a conspicuos obispos y hasta al Cardenal Errázuriz y al propio arzobispo de Santiago, Ricardo Ezzati, para tomarles declaración.

No obstante, los obispos formados por Karadima seguían hasta agosto último ostentando los cargos en sus respectivas diócesis, como si nada hubiera pasado.

En la etapa final -en julio último- Jessica González careó a las víctimas con el propio Karadima, quien premunido de certificados médicos ad hoc, antes había hecho todo lo posible por evitarlos. Con el juez Valdivieso lo había logrado. Pero la entereza de la ministra pudo más, y el acusado debió volver a encontrarse con esas víctimas que reemplazaron la admiración por el desprecio y el rechazo frontal, como se lo demostraron ante la ministra.

\section{"NO ES EL FUNERAL DE LA IGLESIA"}

La incautación del informe del Vaticano que efectuó la ministra González desde las oficinas del abogado Bulnes en abril -que causó fuerte polémica en el Colegio de Abogados- fue aceptada finalmente por la Corte de Apelaciones. Esa importante pieza, donde figurarían nombres de otras víctimas, pasó a ser así parte del proceso ${ }^{12}$, pese a que desde Roma no había respuesta al exhorto solicitado por la Corte Suprema.

Con todo esto, los cimientos de la Iglesia han sido removidos con inusitada fuerza, aunque eso no se diga con todas sus letras. A tanto ha llegado que el propio arzobispo capitalino y presidente de la Conferencia Episcopal, Ricardo Ezzati, se sintió obligado a precisar hace unos meses que el caso Karadima no es "el funeral de la Iglesia Chilena, como algunos quisieran"13. Si la imagen de un funeral estaba en el subconsciente del

12. Los ministros de la Tercera Sala de la Corte de Apelaciones, Amanda Valdovinos, Javier Moya, y el abogado integrante, Jaime Guerrero, confirmaron la acción desarrollada por la Policía de Investigaciones (PDI) por instrucción de la ministra en visita el 13 de abril de 2010.

13. "Ezzati dice que el caso Karadima 'no es el funeral de la Iglesia", La Tercera, Santiago, 29 de mayo de 2011. 
prelado como para pronunciar esa frase, no es necesario ir más lejos para denotar la gravedad de la situación.

El remezón tiene una profunda dimensión cultural, social, y al fin y al cabo política. No se trata solo de repercusiones religiosas. En un país como Chile, donde la Iglesia católica ha sido tan influyente desde los tiempos de la Colonia, es natural que lo ocurrido tenga implicancias significativas. Y algunas ya se empiezan a vislumbrar.

La Iglesia -en sus 450 años, que ha celebrado en 2011- fue siempre gravitante en la historia del país. Sería largo de analizar su rol en la educación -ha sido y es el principal "sostenedor" de colegios, por ejemplo- y su vinculación a la política. Sin ir más lejos, su relación con partidos confesionales, como lo fue el Conservador en el pasado, las disputas entre Iglesia y Estado laico, la formación y mantención de medios de comunicación -El chileno y el Diario Ilustrado, entre otros- son solo algunas señales de esa influencia. Pero quizás en el Siglo XX lo que más se recuerde sea su preocupación especial por la "cuestión social" y, en tiempos de dictadura, su rol fundamental en la defensa de los derechos humanos, en particular desde la Vicaría de la Solidaridad y de la menos conocida de Pastoral Obrera.

Fue considerada "reserva moral" en tiempos críticos y "voz de los sin voz" cuando el silencio y la represión imperaban. Un capital que en la etapa siguiente le sirvió para constituirse en "poder fáctico" sin muchos contrapesos.

Al final de la dictadura y en las décadas posteriores, que coincidieron con el papado de Juan Pablo II y el reinado de Angelo Sodano en Roma, la Conferencia Episcopal con nueva fisonomía dejaba muy atrás aquellos tiempos de las conferencias de Puebla o Medellín. Con el correr de los años y en plena transición, las preocupaciones moralistas pasaron a estar en el primer plano, mientras cada vez más numerosos católicos se veían marginados de la Iglesia por obispos y curas que -como Karadima- repartían desde el confesionario excomuniones a quienes se separaban y volvían a casar y sentenciaban a las mujeres que tomaban medidas de control de natalidad. Solo de vez en cuando las voces de los obispos -más de unos que de otros- se levantaban preocupadas por "un salario ético" o por las inequidades sociales de Chile, por el modelo de desarrollo instalado o por las limitaciones que presenta la democracia actual.

\section{PROBLEMAS DE CONFIANZA}

La posición beligerante de la Iglesia contra la ley de divorcio -finalmente aprobada en 2004-, o contra la denominada "píldora del día después" todavía resonaban en los oídos de muchos cuando sobrevino el escándalo provocado por Karadima, un hombre que se identificaba con ese ideario conservador y con alta influencia en la Conferencia Episcopal. La caída de su pedestal, poco después que se develara la doble vida de Marcial Maciel, el fundador de los Legionarios de Cristo, en México, son golpes demasiado fuertes y estrepitosos como para no dejar huellas.

Por de pronto, ya se advierte que otras víctimas de abusos de sacerdotes están dando a conocer sus situaciones ante la justicia y la Iglesia. Lo que estaba oculto empieza a develarse bajo la influencia de lo ocurrido respecto al ex cura de El Bosque. 
El caso Karadima estalló en un tiempo especial de este Chile post-Pinochet. Y su proceso judicial culmina cuando diversos grupos de la sociedad levantan sus banderas, cuando los estudiantes universitarios se rebelan contra un modelo de sociedad y de sistema educacional que no les acomoda. Cuando los escolares de enseñanza básica y media, y sus padres, reclaman en las calles por calidad y equidad. Cuando el destape de mentiras y medias verdades se empieza a producir en diversos ámbitos, trae un sano afán de transparencia en toda la sociedad. En cierto modo, una situación "contagia" a la otra, y se producen retroalimentaciones de diversos y numerosos actores que exigen más sinceridad, transparencia y justicia en todos los planos de la vida de la sociedad. El "no" al abuso que surge después de conocer la brutal dominación que ejercía Karadima se proyecta a su vez a otros planos. Ese hablar "de igual a igual" que manifestaron los denunciantes de Karadima parece llegar como un estilo en estos días.

Las réplicas de este terremoto grado diez en la Iglesia pueden llegar -y están llegando- a diferentes ámbitos de la vida ciudadana. Y, por cierto, debieran tocar a la política. Otra cosa diferente es que los políticos que han mostrado en el último tiempo dificultad para conectarse con vivencias y sentimientos de jóvenes y adultos no estén con la sintonía suficientemente fina para detectar las señales que el caso Karadima está dejando.

Karadima instaló en su parroquia un sistema de abuso, donde la dominación psicológica fue el marco que le permitió dar curso al abuso sexual con sus víctimas. Actuó como cabeza de una secta en la que oficiaba, no solo como líder de los jóvenes de la denominada Acción Católica, sino como "director espiritual" de todos los sacerdotes formados por él. Así era hasta hace poco más de un año, cuando estalló el escándalo. Aunque desde 2006 ya no era el párroco, seguía siendo el dueño y señor de El Bosque, con un poder de caudillo espiritual que no tienen ni tenían otros curas.

Si quiere recuperar un sentido que nunca debió perder, desmantelar en profundidad todo eso será tarea fundamental de la Iglesia de Santiago. Y la sociedad -no solo los católicos- deberían estar alertas para que eso ocurra, para que se efectúen las investigaciones necesarias para evitar que eso siga sucediendo en alguna parroquia, en algún colegio o en cualquier lugar.

La credibilidad de la jerarquía católica, y en general de la Iglesia, no podrá ser recuperada mientras esas investigaciones no se lleven a cabo para determinar posibles complicidades y encubrimientos. Asimismo, parece necesario, junto con dar apoyo a esos sacerdotes que eran sus guiados y en cierto sentido quedaron "huérfanos", una revisión de la doctrina, de la espiritualidad de quienes fueron formados por alguien como Karadima. De no hacerlo, la Iglesia se verá enfrentada a un mayor distanciamiento de quienes daban por cierto todo lo que decía, pero que hoy están sumidos en mucha dudas. Y con heridas tan profundas de por medio que hasta las palabras faltan para recomponer confianzas. Son indispensables los hechos. Unas cuantas declaraciones o algunos documentos no lograrán salvar la distancia que se ha generado entre muchos ciudadanos y la Iglesia, a la que observan desconcertados, con profundas sospechas.

Precisamente porque Karadima era uno de los curas más poderos de la Iglesia chilena, su caída es más fuerte para la propia institución. 


\section{AUTOCRACIA EN NOMBRE DE DIOS}

Desde otra perspectiva, el caso Karadima ha puesto en jaque la acción de la jerarquía católica en todo esto. ¿Cómo pudo ocurrir lo que sucedió en El Bosque a vista y paciencia de los jefes de la Iglesia chilena sin que nadie investigara en tantos años? Hay testimonios que indican que desde los 80, cuando era arzobispo el Cardenal José Francisco Fresno hubo algunos indicios de denuncias que cayeron en el vacío. ¿El hecho de que Karadima proveyera de decenas de vocaciones sacerdotales lo hacía intocable? ¿O era su carácter conservador y sus relaciones con el Vaticano que cultivó durante tres décadas era un factor que lo protegía?

Es cierto que la Iglesia católica no es democrática. Y que los intentos de democratización impulsados por el Concilio Vaticano II se vieron truncados. Una característica evidente es la autocracia. Si se la mira con distancia crítica, se la observa como una institución jerárquica, vertical y hermética. Sus procedimientos internos son desconocidos por la mayoría de sus seguidores. No se sabe exactamente cómo se toman las decisiones. No hay una instancia que fiscalice y sus integrantes -sacerdotes, religiosos y fieles- no piden cuentas de lo que ocurre.

Si se aplican a la Iglesia las categorías políticas de un Estado, por ejemplo, se puede observar que en ella la máxima autoridad eclesiástica reúne en sí el poder constituyente, el legislativo, judicial y, desde luego, el ejecutivo. Y toda esa autoridad la asume en nombre de Dios, lo que implica un mandato especial para sus miembros. ¿Qué tipo de decisiones toma la autoridad y por qué lo hace? ¿Qué fuerzas juegan? Son preguntas que muchos se las empiezan a hacer en una sociedad que cada vez quiere y exige más respuestas. Incluso los que van a misa reciben sacramentos y entregan aportes para su funcionamiento o para labores sociales. Y, desde luego, los que tienen a sus hijos en colegios católicos.

Después de haber visto en actitudes poco firmes y unilaterales a un Cardenal Errázuriz, que no acogió a las víctimas de Karadima y que ni siquiera les creyó porque prefirió quedarse con la opinión de un consejero que resultó ser tan poco idóneo como el mismo director de la Pía Unión, Andrés Arteaga, la autoridad del arzobispo también ha quedado cuestionada.

Al percibir equivocaciones como la que tuvo la jerarquía eclesiástica respecto a un personaje del talante de Fernando Karadima, las reflexiones abundan. La justificación del acto porque "Dios lo quiere" subordina la voluntad, y fue así como Karadima subyugó a sus víctimas: identificando su voluntad con la de Dios y recalcando el miedo hacia el demonio.

\section{"CISMA EMOCIONAL"}

En un momento en que el ambiente político y social del país se ha visto agitado por un afán de cambios que dejen atrás las injusticias y abusos, no es descabellado hacerse la pregunta: ¿pedirán en algún momento los católicos explicaciones a sus obispos 
por situaciones como las de Karadima y otros sacerdotes cuyos casos se han conocido después?

El sacerdote jesuita Jorge Costadoat, profesor de la Universidad Católica y de la Universidad Alberto Hurtado, escribía en abril pasado fuertes palabras que hablan de las consecuencias de este terremoto: "Tiene lugar en Chile en este momento un fenómeno inaudito: el levantamiento del laicado católico. También otros que no son católicos pero que llegaron a valorar la acción humanitaria de la Iglesia se sienten defraudados y reclaman airados. Hace ya tiempo para muchos la Iglesia institucional se volvió 'odiosa' al atribuirse una cierta supremacía moral. No pocos católicos entraron en lo que se ha llamado 'cisma emocional': no se han ido de la Iglesia por cariño y fidelidad a ella, pero lo que ella les propone no los interpreta o les es invivible. Lo nuevo que sucede ahora es una especie de indignación abierta y masiva, la expresión a voz en cuello de la rabia, la pena y la desafección con las autoridades de la Iglesia" ${ }^{14}$. Según Costadoat, con el caso Karadima la crisis de la Iglesia ha alcanzado un punto de no retorno. La Iglesia en Chile no volverá a ser la misma, afirma.

Tras la publicación del libro Karadima, el señor de los infiernos he podido palpar el impacto que ha provocado el escándalo protagonizado por el ex cura de la parroquia de El Bosque. En conversaciones y e-mails diferentes personas me han expresado el espanto por la dominación que ejercía sobre sus discípulos y los abusos sexuales cometidos. Y el estupor y la indignación se extienden hacia las autoridades de la Iglesia, que no vieron a tiempo lo que estaba ocurriendo en una de las más influyentes iglesias de Santiago. También surge una suerte de desconfianza, de falta de credibilidad que se viene reflejando en encuestas y estudios.

Todo esto está provocando que la voz de la Iglesia, tan fuerte en las últimas décadas para encarar los denominados temas valóricos que durante años vinieron marcando la agenda, se escuche muy menoscabada, casi afónica. Incluso su posición se advierte debilitada frente a asuntos que le preocupaban tanto y su voz pesada en lo referente a educación.

\section{IGLESIA POST-KARADIMA}

Los reacomodos que producirá el efecto Karadima podrían provocar que otros movimientos ganen algún espacio dentro de la propia Iglesia. Como en el río revuelto de las incertidumbres, desde el Opus Dei -que aparece hasta ahora sin escándalos de este tipo en Chile-podrían eventualmente tender sus redes hacia los desencantados de Karadima y su organización. Ambos grupos tienen una plataforma común en cuanto a la concepción valórica y a la espiritualidad conservadora.

Los Legionarios de Cristo, el otro movimiento de similar raigambre que se había desarrollado notablemente en Chile desde los años 80, han debido soportar su propio

14. Costodat, J., "La Iglesia post Karadima", en Cristo en construcción, 11 de abril 2011, véase: http.://www. jorgecostadoat.cl/2011_04/la-iglesia-post-karadima, [consulta: 30/06/2011] 
escándalo por la doble vida de su fundador Marcel Maciel, un equivalente en México a lo que ha sido Karadima en Chile.

Si los "pescadores" ganadores de esta vuelta resultan ser los del imperio creado por José María Escrivá de Balaguer, implicaría también una repercusión importante en el escenario ideológico y político chileno. El Opus Dei, además de su propia fuerza, que se desarrolla en la Universidad de Los Andes, en los colegios, en diversas "labores" y en el ámbito empresarial, podría seguir creciendo a costa de los "viudos" de Karadima y Maciel que van quedando en este camino.

Jorge Costadoat sostiene que "habrá un Post-Karadima con mayúscula. ¿Cómo será?", se pregunta. Y él mismo afirma que es muy difícil preverlo. "Porque, a decir verdad, se relaciona con un giro histórico, con tremendas mutaciones culturales". En su artículo sobre la iglesia post-Karadima, el sacerdote jesuita va aun más lejos y sostiene que hay "un punto doctrinal crítico", que lo explica así: "La jerarquía de la Iglesia no ha cumplido suficientemente el mandato de un concilio ecuménico. El Vaticano II mandó subordinar el sacerdocio ministerial al servicio del sacerdocio común de los fieles. Si se hubiera acatado el Concilio, habríamos tenido muchos más sacerdotes atentos a los signos de los tiempos, cercanos y compresivos de la dureza de la existencia. Por el contrario, en el post Concilio se ha re-sacralizado al clero, poniéndose a los sacerdotes del lado de lo sacro, protegiéndoselos de la cultura actual, y haciéndoseles reproducir interiormente en ellos el movimiento de distanciamiento de la Iglesia respecto del mundo moderno, cuando no de abierta condena".

Según Costadoat, esa división sociológica Iglesia-mundo se ha replicado psicológicamente en el sacerdote. Anota también que "el mismo sacerdote ha comenzado a dudar de la viabilidad de su celibato. La cultura ya no agradece su sacrificio. Ahora lo critica y sospecha de él. Le refriega en la cara sus fracasos. A los seminaristas se les grita por la calle 'pedófilos'. Pero también a los sacerdotes mayores se les doblan las rodillas. Los que trabajan en colegios y parroquias están agotados de probar día a día su inocencia". Concluye el jesuita: "El sacerdote está trizado. No es nuevo que un sacerdote pueda quebrarse. Lo nuevo es que nunca antes el sacerdocio había sido tan cuestionado".

Costadoat apunta también a un segundo problema: "Crece la desconfianza en la jerarquía. La Iglesia reconoce la investidura sacramental de los obispos, pero la confianza en ella de gran parte del pueblo de Dios sí se quebró. Las autoridades, a los ojos de muchísimos católicos, están desautorizadas y con ello los sacerdotes se encuentran a la intemperie. Esto es lo nuevo. Una desconfianza hacia la autoridad de tal profundidad no parece tener antecedentes en la historia de la Iglesia en Chile".

\section{LA LLAVE PERDIDA}

A lo anterior, el sacerdote jesuita agrega que la Iglesia necesita una jerarquía en quien confiar. "Pero nuestros propios obispos están atrapados. La recuperación de la confianza no depende simplemente de ellos. La crisis aqueja a la Iglesia universal. Solos no podrán cambiar nada de lo que urge cambiar. Si los obispos del mundo, con el Papa a la cabeza, 
no obedece al mandato conciliar de una Iglesia de comunión, no vertical, no clerical, dialogante y atenta a los signos de los tiempos, predominará la desconfianza, el 'cisma emocional' y el éxodo sin más", vaticina Costadoat, quien recurre a una metáfora para remarcar su apreciación: el problema, según él, no se agota en los "Karadimas". Ni en las responsabilidades de monseñor Errázuriz. "Ahora somos los católicos el problema. Somos una Iglesia que cerró las puertas por dentro y no encuentra la llave".

Y agrega: "Monseñor Ezzati nos ha llamado a un diálogo. ¡Entonces conversemos! Pero que hablen todos. Que también hablen los no católicos. Los no creyentes. Pues dudo que la salida la encontremos solos. Tengo una sola idea clara: la 'nueva Iglesia' provendrá de una conversación sincera, sin amagos o palabras acaracoladas".

Si la Iglesia no encuentra la llave, como dice Costadoat, es obvio que su convocatoria espiritual será menor y también su influencia cultural y política. Su poder se verá disminuido. La sociedad tendrá que discutir de modo más democrático y maduro sus problemas sin apelar a que en nombre de Dios o del "derecho natural" se obligue a actuar de determinada manera. Y eso en un país que se identificaba con lo católico desde sus orígenes como nación independiente necesariamente marcará un cambio substancial.

Es importante considerar que esta crisis de la Iglesia ocurre en un momento en que la política está menoscabada como actividad y en que los partidos que dieron respaldo histórico a la Iglesia Católica no tienen mucho que decir a favor de ella. Los fallidos intentos de defensa de Karadima de aquellos días de abril de 2010 ya no se repiten hoy. Tampoco se ha visto a quienes podrían considerarse más cercanos al Episcopado, muy interesados en otorgar su aval en estos tiempos de debilidad. Ni la UDI ni RN más preocupados de hacer gobierno en coalicación, con sus problemas y cuitas, lo han hecho. Tampoco la DC, que antes fue cercana. Nadie parece dispuesto a arriesgar en este juego de confianzas perdidas.

Cuando la Iglesia Católica en Chile conmemora 450 años de existencia aparece así en un trance complejo y expuesta a pruebas difíciles de superar. La "voz del pueblo", que se puede percibir a través de la calle, las encuestas y de los nuevos espacios que plantean los blogs y las redes sociales, se advierte alejada de los partidos, pero también de esta institución cuestionada. Y se dibuja un gran signo de interrogación sobre cómo será la existencia de la Iglesia chilena después de Karadima.

Surge también la pregunta de cómo será la política en Chile que, más allá de todos las otras profundas revisiones que debería hacer, no tendrá el fuerte peso específico de ese "poder fáctico" que había representado la Iglesia hasta antes de explotar el efecto Karadima.

Esa historia está por escribirse. A partir del año 451.

\section{REFERENCIAS BIBLIOGRÁFICAS}

Costodat, J., "La Iglesia post Karadima", en Cristo en construcción, 11 de abril 2011, véase: http.:// www.jorgecostadoat.cl/2011_04/la-iglesia-post-karadima, [consulta: 30/06/2011

Mönckeberg, Ma O., Karadima, el señor de los infiernos, Santiago: Debate, 2011. 